\title{
[1:3] Site-differentiated and sulfide-bridged cubane clusters in chemistry and biology
}

\author{
R. H. Holm
}

Department of Chemistry and Chemical Biology, Harvard University, Cambridge, Massachusetts 02138, U.S.A.

\begin{abstract}
A subset of protein-bound $\mathrm{Fe}_{4} \mathrm{~S}_{4}$ cubane-type clusters occurs in a [1:3] iron site-differentiated form in which the terminal ligand at the unique site is not a cysteinyl group. Reactions of synthetic site-differentiated $\left[\mathrm{Fe}_{4} \mathrm{~S}_{4}\right]^{2+}$ clusters are summarized, including removal of the unique iron atom to afford the $\left[\mathrm{Fe}_{3} \mathrm{~S}_{4}\right]^{0}$ cuboidal cluster, thereby completing the synthesis of analogues of native iron-sulfur clusters with nuclearity $\leq 4$. The cuboidal cluster supports metal ion insertion reactions leading to a set of heterometal cubane type clusters $\mathrm{MFe}_{3} \mathrm{~S}_{4}$, whose redox potentials have been determined as a function of $\mathrm{M}$. Sulfide-bridged double cubanes $\left[\mathrm{MFe}_{3} \mathrm{~S}_{4}\right]-\mathrm{S}-\left[\mathrm{MFe}_{3} \mathrm{~S}_{4}\right]\left(\mathrm{M}=\mathrm{Mo}, \mathrm{Fe} ; \mathrm{M}_{2}=\mathrm{MoFe}\right)$, another type of site-differentiated cluster, have been prepared as precursors in potential cluster rearrangement reactions leading to the core $\left[\mathrm{MFe}_{6} \mathrm{~S}_{9}\right]$ with the same topology as the FeMo-cofactor of nitrogenase.
\end{abstract}

\section{INTRODUCTION}

The pervasiveness in biology of iron-sulfur clusters containing the rhomboidal $\mathrm{Fe}_{2}\left(\mu_{2}-\mathrm{S}\right)_{2}$, cuboidal $\mathrm{Fe}_{3}\left(\mu_{2}-\right.$ $S)_{3}\left(\mu_{3}-S\right)$ and cubane-type $\mathrm{Fe}_{4}\left(\mu_{3}-\mathrm{S}\right)_{4}$ cores is well recognized $(1,2)$. Over a $\mathrm{ca}$. 25 -year period, cluster structures have been established by protein crystallography (3), physicochemical properties elucidated in considerable detail, and analogue clusters synthesized. These clusters are conventionally bound to proteins entirely through S.Cys ligands, in which form they have an electron storage and transfer function. Of particular current interest are $\mathrm{Fe}_{4} \mathrm{~S}_{4}$ clusters that are rendered [1:3] site-differentiated by virtue of non-cysteinyl coordination at one iron site. The chemistry of these clusters is considerably expanded beyond electron transfer by this departure from standard terminal ligation. Native [1:3] site-differentiated clusters 1-4 are set out in Fig. 1. Cluster 1 is the catalytic center in aconitase and certain other hydro-lyases (4). Substrate is bound, activated, and transformed at the unique iron site. Under our previous definition, sites $\mathbf{2}$ and $\mathbf{3}$ are biological bridged assemblies (5). Assembly 2 represents the two different catalytic centers of carbon monoxide dehydrogenase (Clostridium thermoaceticum) (6), center A for acetyl coenzyme A synthase activity and center $\mathrm{C}$ for $\mathrm{CO} / \mathrm{CO}_{2}$ interconversion. In each, a nickel atom with a coordination sphere of incompletely defined geometry and ligation is bridged through an unknown atom or group $\mathrm{X}$ to one site of an $\mathrm{Fe}_{4} \mathrm{~S}_{4}$ cluster.

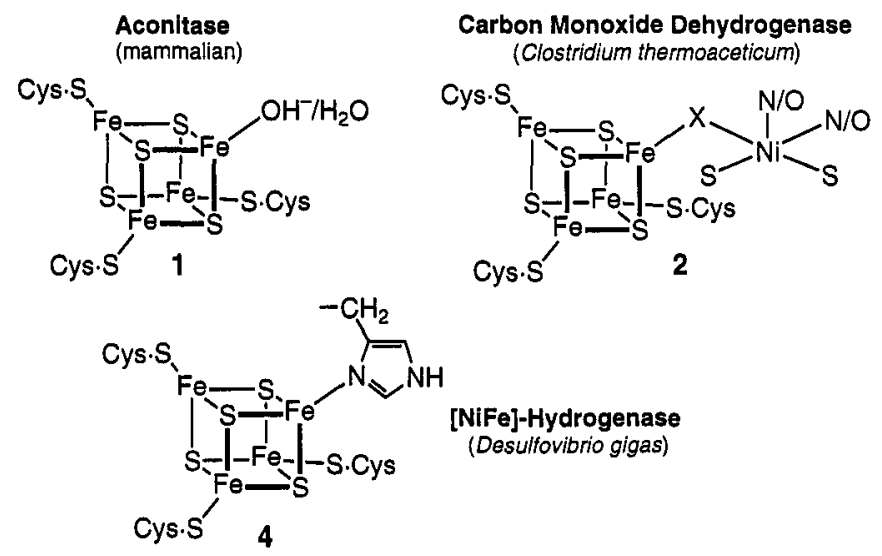

Fig. 1. Native [1:3] Site-Differentiated $\mathrm{Fe}_{4} \mathrm{~S}_{4}$ Clusters

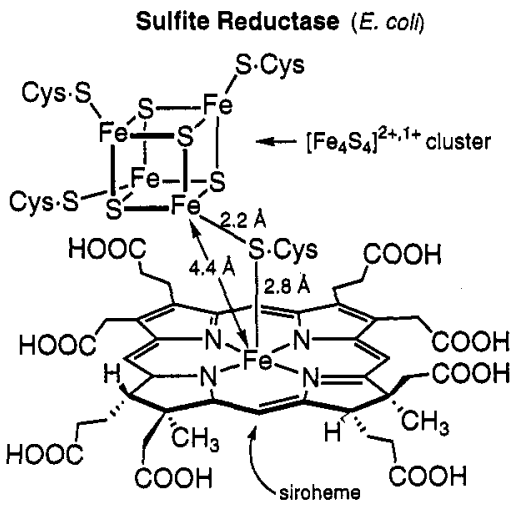

3 
Assembly 3 is the active site of sulfite reductase (Escherichia coli) (7), wherein a siroheme group is coupled to an $\mathrm{Fe}_{4} \mathrm{~S}_{4}$ cluster through its unique iron site by means of an $\mathrm{Fe}-\left(\mu_{2}\right.$-S.Cys $)-\mathrm{Fe}$ bridge containing one very long bond. Substrate is bound in an axial position trans to the bridge, and electrons are presumably injected one at time into the cluster and flow to siroheme and then to substrate. Cluster 4 is the distal component in the linear cluster arrangement $\mathrm{Fe}_{4} \mathrm{~S}_{4}\left|\mathrm{Fe}_{3} \mathrm{~S}_{4}\right| \mathrm{Fe}_{4} \mathrm{~S}_{4}$, which is apparently the conduit for electron flow in the uptake [NiFe]-hydrogenase of Desulfovibrio gigas (8). This is the only proven example of imidazole ligation to a native $\mathrm{Fe}_{4} \mathrm{~S}_{4}$ cluster. These and other observations over the last decade, including formation of proteinbound $\mathrm{Fe}_{3} \mathrm{~S}_{4}$ clusters from [1:3] clusters (9), have made imperative the development of site-differentiating ligands that facilitate an extensive examination of the chemistry of such clusters.

\section{SYNTHETIC [1:3] SITE-DIFFERENTIATED $\mathrm{Fe}_{4} \mathrm{Q}_{4}$ CLUSTERS}

Two types of site-differentiating ligands have been developed in this laboratory (10-12). The more successful is the semirigid trithiolate cavitand ligand $\mathrm{LS}_{3}$, which is configured to bind efficiently cubane-type $\mathrm{Fe}_{4} \mathrm{Q}_{4}$ cores as the clusters $\left[\mathrm{Fe}_{4} \mathrm{Q}_{4}\left(\mathrm{LS}_{3}\right) \mathrm{L}^{\prime}\right]^{\mathrm{z}}(\mathbf{5})$. The indicated mode of cluster binding has been proven crystallographically $(11,13)$. In the $a b a b a b$ conformation shown, three coordinating arms $(a)$ are buttressed on the same side of the central benzene ring by the three $p$-tolylthio legs $(b)$. Regiospecific substitution reactions occur at the unique iron site. About 100 clusters with various ligands L' (Q $=\mathrm{S}, \mathrm{Se}$ ) have been generated in solution and/or isolated; without exception, their ${ }^{1} \mathrm{H}$ NMR spectra indicate trigonal symmetry in solution. The clusters 5 have been applied to a number of problems: (i) synthesis of a large set of substituted clusters $(11,13-16)$, including factors such as stabilization of five- and six-coordinate unique sites with attendant modulation of redox potentials, charge distribution, and cluster spin state $(15,16)$; (ii) formation of bridged double cubanes with independent and coupled electron transfer reactions across bridges of variable length $(14,17,18)$; (iii) synthesis of sulfide-bridged analogues of assembly 3 (19); (iv) elucidation of comparative isotropic shifts, redox potentials, and ligand binding affinities of $\left[\mathrm{Fe}_{4} \mathrm{~S}_{4}\right]^{2+}$ and $\left[\mathrm{Fe}_{4} \mathrm{Se}_{4}\right]^{2+}$ clusters (13); (v) preparation of cuboidal

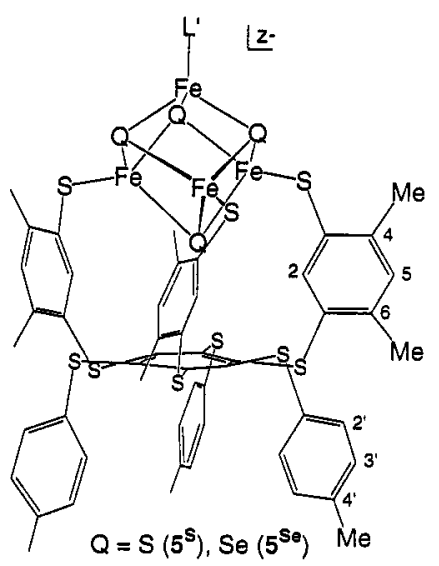
$\left[\mathrm{Fe}_{3} \mathrm{~S}_{4}\left(\mathrm{LS}_{3}\right)\right]^{3-}$ by iron atom removal (20); (vi) formation of heterometal cubane clusters by metal ion insertion into a cuboidal cluster (21). Applications (i)-(iv) have been made possible largely by the hypersensitivity of the isotropically shifted ' $\mathrm{H}$ resonances of the $\left[\mathrm{Fe}_{4} \mathrm{Q}_{4}\right]^{2+}$ clusters 5 to the nature of $\mathrm{L}$ '.

The isotropic components of the chemical shifts of the 4-Me, 5-H, and 6-Me substituents of 5 in the $\left[\mathrm{Fe}_{4} \mathrm{Q}_{4}\right]^{2+}$ oxidation state are mainly or exclusively contact in origin, and for this reason are responsive to changes in the ligand $L^{\prime}$. Figure 2 represents a partial summary of the substitution reactions at the unique iron site $(10,11$, 13-20) monitored by ' $\mathrm{H}$ NMR. Although others may be used, $\left[\mathrm{Fe}_{4} \mathrm{Q}_{4}\left(\mathrm{LS}_{3}\right) \mathrm{Cl}^{2-}(6)\right.$ are convenient starting clusters owing to the lability of chloride. Clusters with anionic ligands (7-17), including those with 5-

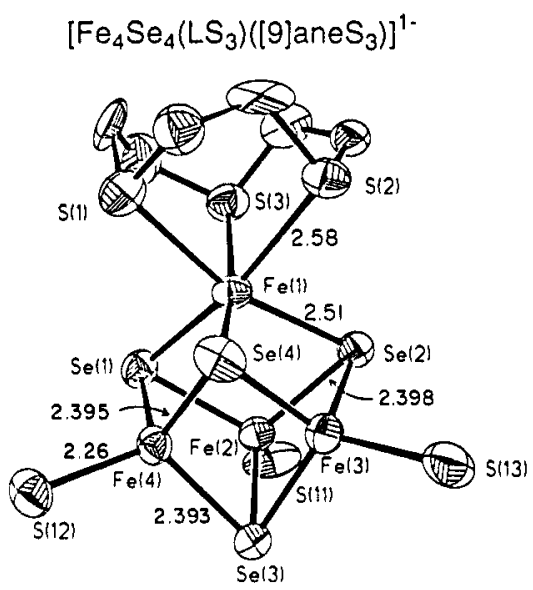

19 coordinate sites (9-11) and bridges between two clusters (12-15), are readily formed. Neutral ligands can be introduced, as in clusters 18-21 which include examples of six-coordinate sites $(18,19)$. A number of useful results follow from the substituted clusters, of which two related to application (i) are noted here. The structure of $\left[\mathrm{Fe}_{4} \mathrm{Se}_{4}\left(\mathrm{LS}_{3}\right)\left([9] \mathrm{aneS}_{3}\right)\right]^{1-}(\mathbf{1 9})$ proves that an iron site in a $\left[\mathrm{Fe}_{4} \mathrm{Q}_{4}\right]^{2+}$ cluster can stabilize six-coordination with nonoxygen ligands. In the enzyme-inhibitor complexes of aconitase (4b), five- and six-coordinate sites $\mathrm{FeS}_{3} \mathrm{O}_{2,3}$ have been shown crystallographically. An estimate of the intrinsic effect of imidazole ligation on the $\left[\mathrm{Fe}_{4} \mathrm{~S}_{4}\right]^{2+11+}$ redox potential can be obtained from clusters 8 and 20 . In acetonitrile, the difference in potential of the reference cluster $\left[\mathrm{Fe}_{4} \mathrm{~S}_{4}\left(\mathrm{LS} \mathrm{S}_{3}\right)(\mathrm{SEt})\right]^{2-}(\mathbf{8})$ and $\left[\mathrm{Fe}_{4} \mathrm{~S}_{4}\left(\mathrm{LS}_{3}\right)(4-\mathrm{MeIm})\right]^{1-}\left(\mathbf{2 0}, \mathrm{R}^{\prime}=\mathrm{Me}\right)$ is $-330 \mathrm{mV}$; i.e., the latter is more easily reduced as would be expected from is lesser negative charge. However, the potential difference between the 
Fig. 2. Site-Specific Substitution Reactions of $\left[\mathrm{Fe}_{4} \mathrm{Q}_{4}\left(\mathrm{LS}_{3}\right) \mathrm{Cl}\right]^{2-}$

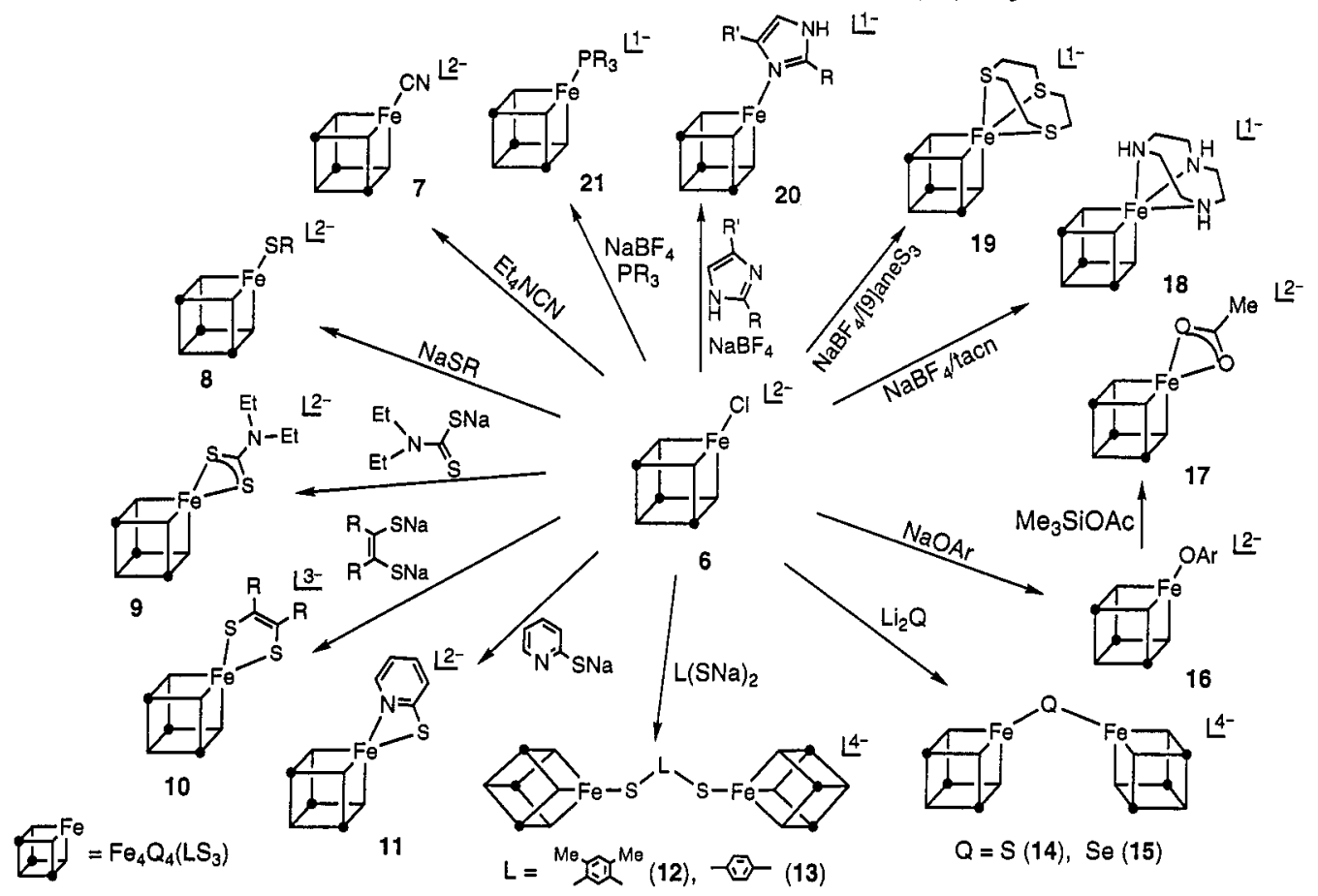

reference $\left[\mathrm{Fe}_{4} \mathrm{~S}_{4}(\mathrm{~S} \cdot \mathrm{Cys})_{4}\right]$ cluster proximal to the active site in $D$. gigas hydrogenase and distal $\left[\mathrm{Fe}_{4} \mathrm{~S}_{4}(\mathrm{~S} \cdot \mathrm{Cys})_{3}(\mathrm{~N} \cdot \mathrm{His})\right](4)$ is only $-60 \mathrm{mV}$ at $\mathrm{pH} 8(22)$. While the sign of the difference is the same as with 8 and 20, evidently there are protein environmental and $\mathrm{pH}$ effects that significantly attenuate the potential difference between the proximal and distal clusters compared to the estimated intrinsic value. Applications (ii), (v), and (vi) and double cubane clusters are considered separately below.

\section{CUBOIDAL $\mathrm{Fe}_{3} \mathrm{~S}_{4}$ CLUSTERS}

Synthesis. The cuboidal cluster $\left[\mathrm{Fe}_{3} \mathrm{~S}_{4}(\mathrm{~S} \cdot \mathrm{Cys})_{3}\right]$ is now commonly encountered in iron-sulfur proteins $(1,9)$, and is recognized by characteristic EPR, MCD, and Mössbauer spectroscopic properties of the $\left[\mathrm{Fe}_{3} \mathrm{~S}_{4}\right]^{1+, 0}$ oxidation states. However, the obtainment of a synthetic analogue has proven to be more difficult than for $\mathrm{Fe}_{2} \mathrm{~S}_{2}$ and $\mathrm{Fe}_{4} \mathrm{~S}_{4}$ clusters, which can be readily prepared by self-assembly methods. The problem was solved by using the reaction scheme in Figure 3 starting with site-differentiated cluster $8(20)$. Labilization of the unique site by thiolate substitution followed by triflate displacement with the fac-tridentate ligand $\mathrm{N}$ methylimidodiacetate (Meida) affords 23. Reaction of the latter with excess Meida gives the desired cluster $\left[\mathrm{Fe}_{3} \mathrm{~S}_{4}\left(\mathrm{LS}_{3}\right)\right]^{3-}(\mathbf{2 4})$ in $76 \%$ yield based on 8 . All steps were performed in acetonitrile; the selenide cluster was prepared by an analogous reaction scheme. The cluster can also be synthesized by the reaction of the cubanetype cluster $\left[(\mathrm{OC})_{3} \mathrm{MoFe}_{3} \mathrm{~S}_{4}\left(\mathrm{LS}_{3}\right)\right]^{3 \cdot}$ with $\mathrm{CO}$; the molybdenum fragment is removed as $\left[\mathrm{Mo}(\mathrm{CO})_{6-n}(\mathrm{MeCN})_{n}\right]$ $(n=3-6)(23)$. The cluster core approaches idealized trigonal symmetry. The collective geometrical and
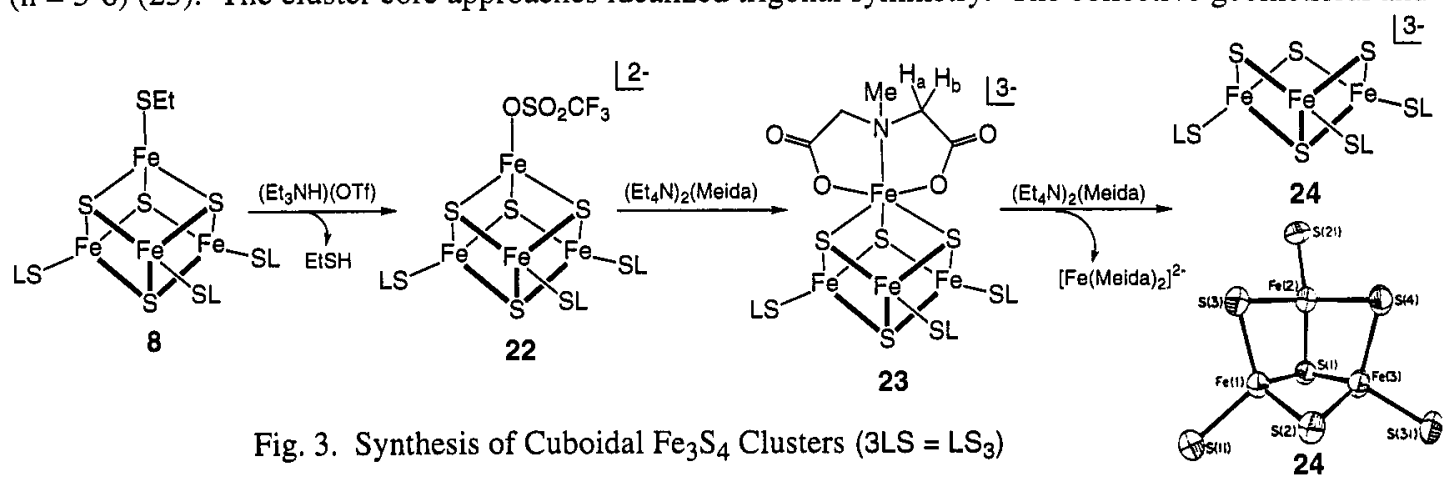

Fig. 3. Synthesis of Cuboidal $\mathrm{Fe}_{3} \mathrm{~S}_{4}$ Clusters $\left(3 L S=L S_{3}\right)$ 
electronic structural data demonstrate that 24 is an accurate analogue of the protein-bound cluster. As such, it demonstrates several important points. Protein structure itself is not necessary to stabilize cuboidal geometry. However, the semirigid $\mathrm{LS}_{3}$ ligand substantially enhances stability inasmuch as its replacement with simple monothiolate ligands results in relatively rapid cluster decay (20). The $S=2$ ground state of protein-bound $\left[\mathrm{Fe}_{3} \mathrm{~S}_{4}\right]^{0}$ clusters, arising from antiparallel coupling of the $\mathrm{S}=9 / 2$ spin from double exchange within an $\mathrm{Fe}^{3+} \mathrm{Fe}^{2+}$ pair and $\mathrm{S}=5 / 2$ of an $\mathrm{Fe}^{3+}$ site, and attendant Mössbauer and magnetic parameters are reproduced almost exactly by $\mathbf{2 4}(20)$. Therefore, this electronic state is an intrinsic property of cuboidal $\left[\mathrm{Fe}_{3} \mathrm{~S}_{4}\right]^{0}$, not set by protein structure.

Metal Ion Incorporation. While the cuboidal $\mathrm{Fe}_{3} \mathrm{~S}_{4}$ cluster has been detected in over 30 proteins, its biological function other than electron transfer remains unclear. The best recognized non-redox reaction of protein-bound clusters is metal-ion incorporation. Incubation of a protein with excess metal salt followed by chromatographic purification affords $\mathrm{MFe}_{3} \mathrm{~S}_{4}$ clusters, which may be oxidized or reduced in subsequent reactions $(24,25)$. Their cubane-type structures have been established by spectroscopy and comparison with synthetic clusters of known structure (26). Thus far, clusters with the cores $\left[\mathrm{MFe}_{3} \mathrm{~S}_{4}\right]^{2+, 1+}(\mathrm{M}=\mathrm{Mn}, \mathrm{Co}, \mathrm{Ni}$, $\mathrm{Cu}, \mathrm{Zn}, \mathrm{Cd}, \mathrm{Tl}$ ) have been identified in proteins. Isolation of 24 permits the investigation of incorporation reactions under near-stoichiometric conditions in synthetic systems (21). Leading results are summarized in Fig. 4, where it is shown that 24 binds $\mathrm{M}^{2+}=\mathrm{Fe}(\mathbf{6}), \mathrm{Co}(\mathbf{2 5}), \mathrm{Ni}(\mathbf{2 6}), \mathrm{M}^{1+}=\mathrm{Cu}(\mathbf{2 7}, \mathbf{2 8}), \mathrm{Tl}(\mathbf{3 0}), \mathrm{Ag}(\mathbf{3 1}, \mathbf{3 2})$, and $\mathrm{M}^{0}=\mathrm{Mo}, \mathrm{W}(29)$, and is, therefore, a cluster ligand. Clusters are isolated in the $\left[\mathrm{MFe}_{3} \mathrm{~S}_{4}\right]^{\circ}(29)$ and $\left[\mathrm{MFe}_{3} \mathrm{~S}_{4}\right]^{1+}$ (all others) oxidation states. Spectroscopic results have shown that except for $\mathbf{2 5}$ and $\mathbf{2 6}$, with the $\left[\mathrm{Fe}_{3} \mathrm{~S}_{4}\right]^{1-}(\mathrm{S}=5 / 2)$ fragment bound to $\mathrm{M}^{2+}$, the clusters contain $\left[\mathrm{Fe}_{3} \mathrm{~S}_{4}\right]^{0}(\mathrm{~S}=2)$ coordinated to $\mathrm{M}^{1+, 0}$. Redox reactions largely change the electron distribution in the $\mathrm{Fe}_{3} \mathrm{~S}_{4}$ portions of the clusters. The dinegative clusters in Fig. 4 permit determination of the heterometal dependence of redox potential for the couple $\left[\mathrm{MFe}_{3} \mathrm{~S}_{4}\right]^{1+10}$ at constant cluster charge and terminal ligands. For 25-27, 30 (M ligand absent), and 32 in acetonitrile, the

Fig. 4. Formation of Heterometal Clusters $\left[\mathrm{MFe}_{3} \mathrm{~S}_{4}\right]$

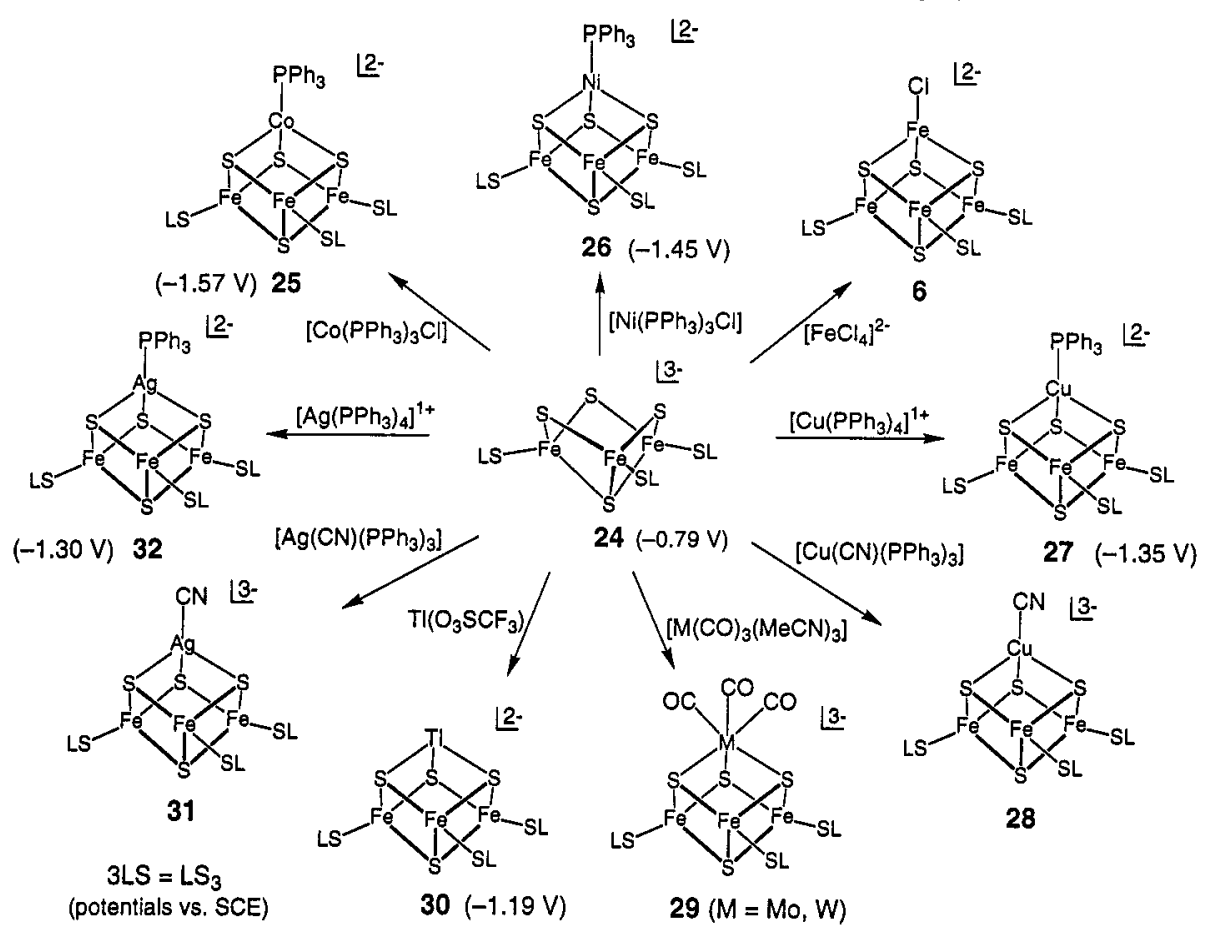

interval of potentials is $c a .400 \mathrm{mV}$ and the order is $\mathrm{Co}<\mathrm{Ni}<\mathrm{Cu} s \mathrm{Ag}<\mathrm{Tl}(21)$. We take this to be the intrinsic order. Progressions of protein-bound cluster potentials are not invariant among proteins and do not tend to follow this order (24); however, terminal ligands at the $M$ sites are unestablished and protein environmental effects are unknown. Because the potential of the couple $[24]^{2 \cdot / 3-}\left(\left[\mathrm{Fe}_{3} \mathrm{~S}_{4}\right]^{1+10}\right)$ is $-0.79 \mathrm{~V}$ in acetonitrile vs. SCE, incorporated heterometal ions afford clusters whose potentials (Fig. 4) for the same 
cluster and core charge couples are some 400 to $800 \mathrm{mV}$ lower than that of the free cuboidal cluster. The $\left[\mathrm{MFe}_{3} \mathrm{~S}_{4}\right]^{0}$ oxidation state apparently requires potentials too negative for stabilization in proteins in aqueous solution. Metal ion incorporation is a new reaction category for synthetic iron-sulfur clusters. With the exception of highly thiophilic $\mathrm{Cu}^{1+}$ and $\mathrm{Tl}^{1+}$ in the cores $\left[\mathrm{MFe}_{3} \mathrm{~S}_{4}\right]^{2+}$, heterometal binding requires the $\left[\mathrm{Fe}_{3} \mathrm{~S}_{4}\right]^{0,1-}$ oxidation states, in which the $\mu_{2}-\mathrm{S}$ atoms are more nucleophilic. All earlier $\mathrm{MFe}_{3} \mathrm{~S}_{4}$ clusters were synthesized by self-assembly reactions or reductive rearrangement of linear $\mathrm{Fe}_{3} \mathrm{~S}_{4}$ clusters $\left(\mathrm{M}^{1+0}+\left[\mathrm{Fe}_{3} \mathrm{~S}_{4}\right]^{1+}\right.$ $\left.\rightarrow\left[\mathrm{MFe}_{3} \mathrm{~S}_{4}\right]^{2+1+}(26)\right)$. The possible natural occurrence of $\mathrm{MFe}_{3} \mathrm{~S}_{4}$ clusters is a matter of continuing interest.

\section{BRIDGED CLUSTER ASSEMBLIES}

Nitrogenase Clusters. Lest one consider that the challenge of understanding native iron-sulfur clusters at a rational level of detail has largely been met, attention is directed to the metal clusters of nitrogenase (27), the P-cluster 33 and the cofactor cluster 34 ( $\mathrm{M}$ or FeMo-co) whose cores have the composition $\mathrm{Fe}_{8} \mathrm{~S}_{7}$ and $\mathrm{MoFe}_{7} \mathrm{~S}_{9}$, respectively. The seminal contributions by Rees and coworkers (28) in the Xray structure determination of nitrogenase proteins has reinvigorated the field of iron-sulfur chemistry and biochemistry, and introduced a new level of complexity and sophistication into the subject of natural and synthetic ironsulfur clusters. The complexity derives from the structures themselves, originating only in a protein venue and manifesting the highest nuclearity of any protein-bound metal-sulfur cluster, and imposes upon the ultimate disclosure of cluster formation, properties, and function a level of sophistication exceeding that required for the smaller clusters. Cluster $\mathbf{3 3}$ in the $\mathrm{P}^{\mathrm{OX}}$ paramagnetic oxidation state (not shown) consists of an $\mathrm{Fe}_{4} \mathrm{~S}_{4}$ cluster with one $\mu_{4}-\mathrm{S}$ atom bound to an iron atom of an $\mathrm{Fe}_{3} \mathrm{~S}_{4}$ cuboidal fragment. In the more reduced $\mathrm{P}^{\mathrm{N}}$ state, this atom becomes at least $\mu_{5}$, interacting with two iron atoms of the cuboidal fragment at $2.4 \AA$; a third iron atom (dashed line) is located
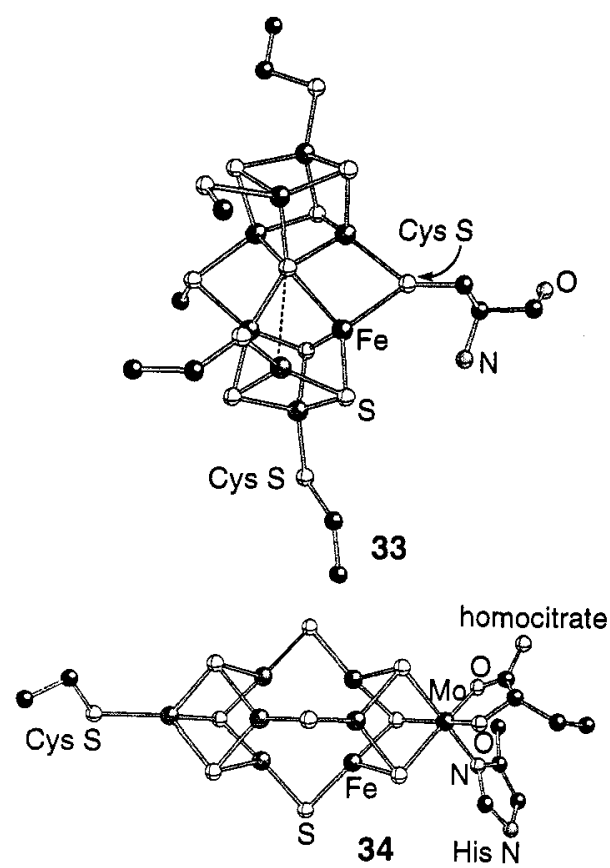

at $2.9 \AA$. In both states, the two cluster fragments are bridged by two Cys.S ligands. (These structures supplant an earlier version in which two $\mathrm{Fe}_{4} \mathrm{~S}_{4}$ clusters were connected by a S-S bond (27)). In passing from $\mathrm{P}^{\mathrm{OX}}$ to $\mathrm{P}^{\mathrm{N}}$, several changes in terminal ligation occur concomitant with an increase in interfragment $\mathrm{Fe}-\mathrm{S}$ bonds (28). Cluster 34 is composed of $\mathrm{Fe}_{4} \mathrm{~S}_{3}$ and $\mathrm{MoFe}_{3} \mathrm{~S}_{3}$ cuboidal fragments bridged by three $\mu_{2}-\mathrm{S}$ atoms which are bound to three-coordinate iron atoms. This structure is maintained in the diamagnetic $\mathrm{M}^{\mathrm{Ox}}$ and the paramagnetic $\mathrm{M}^{\mathrm{N}}(\mathrm{S}=3 / 2)$ states. The P-cluster apparently is the ultimate electron donor to FeMo-co, which is the catalytic site for dinitrogen reduction. Because FeMo-co can be removed with core intact from the protein by disruption of the Fe-S.Cys and Mo-N.His interactions in 34, it has long been recognized as a potentially viable object of synthesis. When not ensconced in a protein environment that controls gated electron and proton flux to the site of catalysis, the cofactor itself is not expected to effect ammonia formation from dinitrogen. However, its preparation in substantial yield from non-protein components must involve new concepts and reactions in cluster synthesis, and the study of accessible oxidation states and their interactions with substrates should be most informative.

Sulfide-Bridged Double Cubanes. One conceptual route to clusters with the topology of $\mathbf{3 4}$ begins with this largely uninvestigated cluster type. The first evidence that $\mathrm{Fe}_{4} \mathrm{~S}_{4}$ clusters could be linked occurred in the form of the double cubane clusters 12-14, which are derived from site-differentiated 6 by chloride displacement (Fig. 2) (17). Shortly thereafter, it was shown that undifferentiated $\left[\mathrm{Fe}_{4} \mathrm{~S}_{4} \mathrm{Cl}_{4}\right]^{2-}$ reacts with stoichiometric $\mathrm{Li} 2 \mathrm{~S}$ to form $\left\{\left[\mathrm{Fe}_{4} \mathrm{~S}_{4} \mathrm{Cl}_{3}\right]_{2} \mathrm{~S}\right\}^{4}$, whose bridged double cubane structure was established by an $\mathrm{x}$-ray structure determination (29). Note that the $\left[\mathrm{Fe}_{4} \mathrm{~S}_{4}\right]-\mathrm{S}-\left[\mathrm{Fe}_{4} \mathrm{~S}_{4}\right]$ core of double cubanes has the same sulfur-metal ratio as $\mathrm{M}_{2} \mathrm{Fe}_{6} \mathrm{~S}_{9}$, where $\mathrm{M}=\mathrm{Mo}+\mathrm{Fe}$ in $\mathbf{3 4}$ and $\mathrm{Mo}$ or $\mathrm{Fe}$ in possible symmetrized synthetic clusters. Removal of suitably labile ligands (chloride, aryloxide) by chemical reaction or dissociation (e.g., triflate) followed by 
core rearrangement could yield the FeMo-co topology, as in the generalized core reaction $\left[\mathrm{MFe}_{3}\left(\mu_{3}-S\right)_{4}\right]_{2}\left(\mu_{2}-S\right)$ $\rightarrow\left[\mathrm{MFe}_{3}\left(\mu_{3}-S\right)_{3}\right]_{2}\left(\mu_{2}-S\right)_{3}$. To proceed with this concept (18), it was first necessary to develop a synthetic scheme for double cubanes and means of structure proof without complete reliance on $x$-ray crystallography, in the event that such compounds could not always be crystallized.

The heterogenous reactions $\left[\mathrm{Fe}_{4} \mathrm{Q}_{4}\left(\mathrm{LS}_{3}\right) \mathrm{Cl}\right]^{2-}+\mathrm{Li}_{2} \mathrm{Q}\left(\right.$ or $\left.\mathrm{Na}_{2} \mathrm{~S}\right) \rightarrow\left\{\left[\mathrm{Fe}_{4} \mathrm{Q}_{4}\left(\mathrm{LS}_{3}\right)\right]_{2} \mathrm{Q}\right\}^{4-}(\mathbf{1 4}, 15)$ in acetonitrile afford ca. $90 \%$ yields of the product clusters. The double cubane structure of $\mathbf{1 5}$ was proved crystallographically (18). In this case, the asymmetric unit contained two cluster anions with the indicated bridge angles, leading to intercubane $\mathrm{Fe} \cdots \mathrm{Fe}$ separations of $3.85 \AA$ and $3.79 \AA$. This cluster, 14, and $\left\{\left[\mathrm{Fe}_{4} \mathrm{~S}_{4} \mathrm{Cl}_{3}\right]_{2} \mathrm{~S}\right\}^{4-}$ proved useful for developing two non-crystallographic criteria for sulfide-bridged double cubane formation (18). (i) Cluster parent ions (associated with $\mathrm{R}_{4} \mathrm{~N}^{+}$counterions), having characteristic isotope patterns, are observable by electrospray mass spectrometry. (ii) Two distinct reduction steps, separated by $250-310$

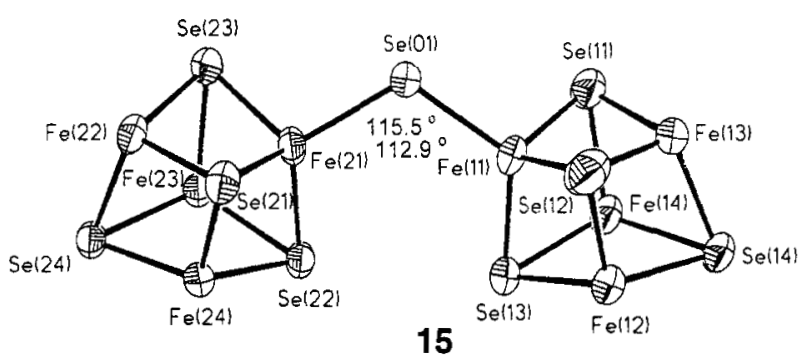
$\mathrm{mV}$ in acetonitrile, are found in voltammetry.

Related single cubanes show one such step, always at less negative potentials, indicating the stepwise reduction of individual clusters $\left(\left[\mathrm{Fe}_{4} \mathrm{~S}_{4}\right]^{2+1++}\right)$ in intact double cubanes. These criteria are also expected to apply to heterometal sulfide-bridged double cubanes, and closely related species. Among the latter is $\left[\mathrm{VFe}_{4} \mathrm{~S}_{6}\left(\mathrm{PEt}_{3}\right)_{4}\right]_{2} \mathrm{~S}$, derived from the cuboidal cluster $\left[\mathrm{VFe}_{4} \mathrm{~S}_{6}\left(\mathrm{PEt}_{3}\right)_{4} \mathrm{Cl}\right](30)$, which meets these criteria and in addition shows two discrete oxidation steps (18).

Synthesis of sulfide-bridged heterometal double cubanes is somewhat more involved because it requires the preparation of appropriate single-cubane precursors. The latter are, however, members of a widely explored group of heterometal $\mathrm{MFe}_{3} \mathrm{~S}_{4}$ cubanes (9). One reaction scheme that has been developed is set out in Fig. 5 (18). The cluster $\left[\left(\mathrm{C}_{6} \mathrm{Cl}_{4} \mathrm{O}_{2}\right)(\text { solv }) \mathrm{MoFe}_{3} \mathrm{~S}_{4} \mathrm{Cl}_{3}\right]^{2-}(\mathbf{3 5}$, cat $=$ catecholate(2-)), available in three steps from a

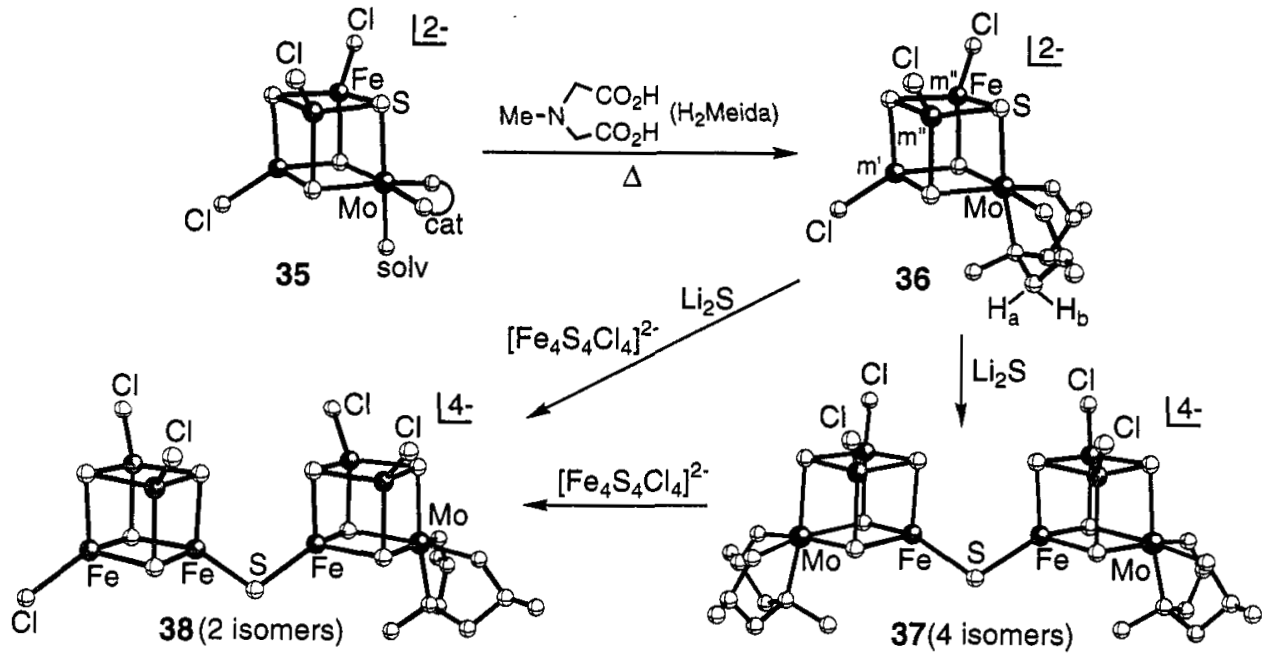

Fig. 5. Formation of Sulfide-Bridged Double Cubanes

self-assembled bridged double cubane (31), is converted by site-specific ligand substitution to [(Meida) $\left.\mathrm{MoFe}_{3} \mathrm{~S}_{4} \mathrm{Cl}_{3}\right]^{2-}(36)(18,32)$, containing a tight-binding tridentate ligand to prevent bridge formation at the Mo site. This cluster has mirror symmetry, two types of iron sites ( $\left.\mathrm{m}^{\prime}, \mathrm{m}^{\prime \prime}\right)$, and diastereotopic methylene protons $\left(\mathrm{H}_{\mathrm{a}, \mathrm{b}}\right)$. Coupling of $\mathbf{3 6}$ with $\mathrm{Li}_{2} \mathrm{~S}$ affords the symmetrical double cubane $\mathbf{3 7}$ which, owing to different relative arrangements of the two Meida ligands, exists as four geometrical isomers. This compound was isolated as $\left(\mathrm{Et}_{4} \mathrm{~N}\right)_{4}[37] \cdot 2 \mathrm{LiCl}$ in $64 \%$ yield from reaction 1 in acetonitrile. The presence of isomers is indicated by multiple isotropically shifted $\mathrm{H}_{a, b}$ signals and ${ }^{19} \mathrm{~F}$ resonances of the substitution product of 37 , 
$\left\{\left[\left(\text { Meida) } \mathrm{MoFe}_{3} \mathrm{~S}_{4}\left(\mathrm{~S}-p-\mathrm{C}_{6} \mathrm{H}_{4} \mathrm{~F}\right)_{2}\right]_{2} \mathrm{~S}\right\}^{4-}\right.$. Despite multiple attempts, it has not proven possible to obtain diffraction-quality crystals of any compound containing 37 . However, cluster 37 meets criteria (i) and (ii) for a sulfide-bridged structure; in DMF two reduction steps are observed for $\mathbf{3 7}(-1.01,-1.34 \mathrm{~V}$ vs. SCE) compared to one step for $\mathbf{3 6}(-0.81 \mathrm{~V})$. In addition to the formation of 37 , it is also possible to generate unsymmetrical sulfide-bridged double cubane 38 in two systems, both demonstrated to be reversible equilibria in $\mathrm{Me}_{2} \mathrm{SO}$. Cluster 38 can exist as two isomers, depending on whether the bridge is formed at an $\mathrm{m}$ ' or $\mathrm{m}$ " site. When the solid isolated from reaction 2 was redissolved in $\mathrm{Me}_{2} \mathrm{SO}$, the product mol ratio 38:37:36 $\approx$ 9:3:1. Equimolar reaction 3 was also shown to generate 38 together with 36 . Double cubane 38 was positively

$$
\begin{aligned}
2\left[(\text { Meida }) \mathrm{MoFe}_{3} \mathrm{~S}_{4} \mathrm{Cl}_{3}\right]^{2-}+\mathrm{Li}_{2} \mathrm{~S} & \rightarrow\left\{\left[(\mathrm{Meida}) \mathrm{MoFe}_{3} \mathrm{~S}_{4} \mathrm{Cl}_{2}\right]_{2} \mathrm{~S}\right\}^{4-}+2 \mathrm{LiCl} \\
3\left[(\text { Meida }) \mathrm{MoFe}_{3} \mathrm{~S}_{4} \mathrm{Cl}_{3}\right]^{2-}+3\left[\mathrm{Fe}_{4} \mathrm{~S}_{4} \mathrm{Cl}_{4}\right]^{2-}+3 \mathrm{Li}_{2} \mathrm{~S} \rightleftharpoons\left\{\left[(\mathrm{Meida}) \mathrm{MoFe}_{3} \mathrm{~S}_{4} \mathrm{Cl}_{2}\right] \mathrm{S}_{\left.\left(\mathrm{Fe}_{4} \mathrm{~S}_{4} \mathrm{Cl}_{3}\right)\right\}^{4-}}\right. & +\left\{\left[(\mathrm{Meida}) \mathrm{MoFe}_{3} \mathrm{~S}_{4} \mathrm{Cl}_{2}\right]_{2} \mathrm{~S}\right\}^{4-}+\left[\left(\mathrm{Fe}_{4} \mathrm{~S}_{4} \mathrm{Cl}_{3}\right)_{2} \mathrm{~S}\right]^{4-}+6 \mathrm{LiCl}
\end{aligned}
$$

$$
\begin{aligned}
\left\{\left[(\mathrm{Meida}) \mathrm{MoFe}_{3} \mathrm{~S}_{4} \mathrm{Cl}_{2}\right]_{2} \mathrm{~S}\right\}^{4-}+ & {\left[\mathrm{Fe}_{4} \mathrm{~S}_{4} \mathrm{Cl}_{4}\right]^{2-} \rightleftharpoons } \\
& \left\{\left[(\mathrm{Meida}) \mathrm{MoFe}_{3} \mathrm{~S}_{4} \mathrm{Cl}_{2}\right] \mathrm{S}\left(\mathrm{Fe}_{4} \mathrm{~S}_{4} \mathrm{Cl}_{3}\right)\right\}^{4-} \\
+ & {\left[(\mathrm{Meida}) \mathrm{MoFe}_{3} \mathrm{~S}_{4} \mathrm{Cl}_{3}\right]^{2-} }
\end{aligned}
$$

identified by mass spectrometry. When the solid from reaction 2 was treated with acetonitrile, only 38 was detected by ${ }^{1} \mathrm{H}$ NMR owing to the low solubility of $\left(\mathrm{Et}_{4} \mathrm{~N}\right)_{2}[37]$. (Any $\left[\left(\mathrm{Fe}_{4} \mathrm{~S}_{4} \mathrm{Cl}_{3}\right)_{2} \mathrm{~S}\right]^{4-}$ present cannot be detected in this way.) These results suggest the stability order $38>37$, with the probable origin being differing steric repulsions across the bridge. There exist conformations of 37 in which the two Meida moieties come into steric contact, whereas in $38 \mathrm{Meida} / \mathrm{Cl}^{-}$interactions are less destabilizing. Conformations of these two clusters have been analyzed, and a stability order including all isomers of each has been deduced (18). In the most crowded conformations, the bridge angle in $\mathbf{3 8}\left(C_{I}\right)$ much more closely approaches the unstrained value of $102^{\circ}$ in $\left\{\left[\mathrm{Fe}_{4} \mathrm{~S}_{4} \mathrm{Cl}_{3}\right]_{2} \mathrm{~S}\right\}^{4-}(29)$ than does the angle in $37\left(C_{l}\right)$, indicating less steric destabilization.
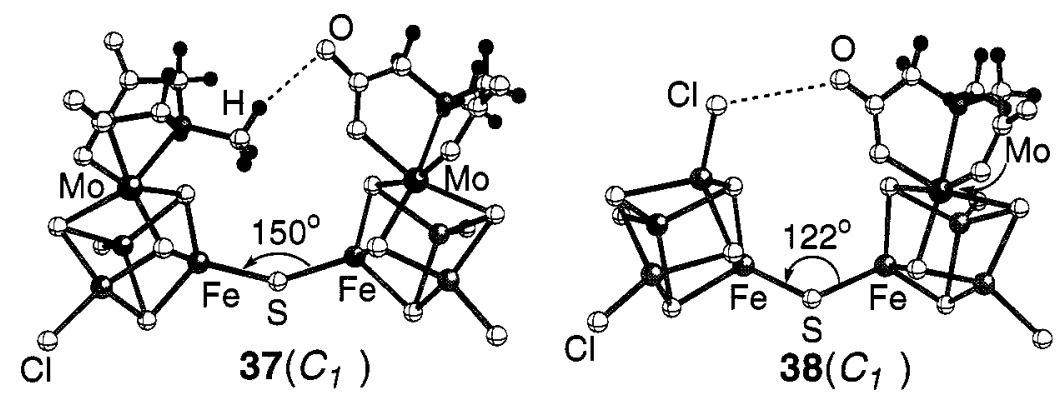

Alternative Approaches to Biological Analogues. By the foregoing means, clusters containing the bridged cores $\left[\mathrm{MoFe}_{3} \mathrm{~S}_{4}-\mathrm{S}-\mathrm{MoFe}_{3} \mathrm{~S}_{4}\right]^{4+},\left[\mathrm{MoFe}_{3} \mathrm{~S}_{4}-\mathrm{S}-\mathrm{Fe}_{4} \mathrm{~S}_{4}\right]^{3+}$, and $\left[\mathrm{Fe}_{4} \mathrm{~S}_{4}-\mathrm{S}-\mathrm{Fe}_{4} \mathrm{~S}_{4}\right]^{2+}$ have been prepared. The compositions of the first and third of these approach that of FeMo-co $\left(34, \mathrm{MoFe}_{7} \mathrm{~S}_{9}\right)$, and the second is identical; $\mathbf{3 8}$ is the first synthetic cluster with this property. These clusters or suitably substituted derivatives serve as viable candidates for the foregoing cluster rearrangement reaction potentially affording one or more of the cores $\left[\mathrm{M}_{2} \mathrm{Fe}_{6} \mathrm{~S}_{9}\right]^{2+}\left(\mathrm{M}=\mathrm{Mo}, \mathrm{Fe} ; \mathrm{M}_{2}=\mathrm{Mo}+\mathrm{Fe}\right)$. It remains to be seen whether the unique and complex structure of FeMo-co can be created without benefit of proteins, its stability outside a protein environment notwithstanding. Current biosynthetic evidence indicates that FeMo-co is assembled on gene products and transferred intact to the apo-MoFe protein of nitrogenase (33). The proteins involved presumably act as scaffolds, on which portions of the cofactor are formed and ultimately combined. Indeed, the problem of nonbiological FeMo-co synthesis raises a broader issue. Can meaningfully close analogues of other bridged assemblies such as $\mathbf{2 , 3}$, and the P-cluster $\mathbf{3 4}$ be synthesized with stability sufficient to allow the development of function? As noted, sulfide-bridged versions of 3 have been prepared (19), but their unsupported bridges render them insufficiently stable for reactivity studies. One synthetic approach to 2 involves a $\mathrm{Ni}\left(\mu_{2}-\mathrm{SR}\right)_{2} \mathrm{Fe}$ bridge between chelated $\mathrm{Ni}(\Pi)$ and an $\left[\mathrm{Fe}_{4} \mathrm{~S}_{4}\right]^{2+}$ cluster (34). These bridged assemblies are prepared by the techniques of small-molecule coordination chemistry and lack several desirable properties, including water solubility. It is apparent that this synthetic protocol is likely to be of limited value in obtaining stable, soluble, and structurally adjustable analogues of bridged biological assemblies. The next generation of significant 
analogues most likely will utilize synthetic peptides alone or in combination with $\alpha$-helical bundles as structural props, engineered so as to optimize the formation, spatial arrangement, and stability of the desired assembly. The means of peptide synthesis and structural analysis are already available. The formation of heme and $\mathrm{Fe}_{4} \mathrm{~S}_{4}$-heme maquettes (35) is a clear demonstration that the peptide binding and scaffolding concept is viable, thus potentiating its application and extension to different types of complex assemblies such as, inter alia, the active sites of sulfite reductase, carbon monoxide dehydrogenase, heme-copper oxidases, [NiFe]hydrogenase, and the clusters of nitrogenase.

Acknowledgements. This research was supported by NIH Grant 28856. I am indebted to my excellent coworkers, whose names appear in the references, for their many contributions.

\section{REFERENCES}

1. R. Cammack, Adv. Inorg. Chem. 38, 281 (1992).

2. H. Beinert, R. H. Holm, and E. Münck, Science, in press.

3. R. H. Holm, P. Kennepohl, and E. I. Solomon, Chem. Rev. 96, 2239 (1996).

4. (a) D. H. Flint and R. M. Allen, Chem. Rev. 96, 2315 (1996). (b) H. Beinert, M. C. Kennedy, and D. C. Stout, Chem. Rev. 96, 2335 (1996).

5. R. H. Holm, Pure Appl. Chem. 67, 217 (1995).

6. (a) S. W. Ragsdale and M.Kumar, Chem. Rev. 96, 2515 (1996). (b) Z. Hu, N. J. Spangler, M. E. Anderson, J. Xia, P. W. Ludden, and E. Münck, J. Am. Chem. Soc. 118, 830 (1996).

7. B. R. Crane, L. M. Siegel, and E. D. Getzoff, Science 270, 59 (1995).

8. A. Volbeda, M. H. Charon, C. Piras, E. C. Hatchikian, M. Frey, and J. C. Fontecilla-Camps, Nature 373, 580 (1995).

9. R. H. Holm, Adv. Inorg. Chem. 38, 1 (1992).

10. R. H. Holm, S. Ciurli, and J. A. Weigel, Prog. Inorg. Chem. 38, 1 (1990),

11. (a) T. D. P. Stack and R. H. Holm, J. Am. Chem. Soc. 110, 2484 (1988). (b) T. D. P. Stack, J. A. Weigel, and R. H. Holm, Inorg. Chem. 29, 3745 (1990)

12. M. A. Whitener, G. Peng, and R. H. Holm, Inorg. Chem. 30, 2411 (1991).

13. C. Zhou and R. H. Holm, Inorg. Chem., 36, in press (1997).

14. J. A. Weigel and R. H. Holm, J. Am. Chem. Soc. 113, 4184 (1991).

15. S. Ciurli, M. Carrié, J. A. Weigel, M. J. Carney, T. D. P. Stack, G. C. Papaefthymiou, and R. H. Holm, J. Am. Chem. Soc. 112, 2654 (1990).

16. J. A. Weigel, K. K. P. Srivastava, E. P. Day, E. Münck, and R. H. Holm, J. Am. Chem. Soc. 112, 8015 (1990).

17. T. D. P. Stack, M. J. Carney, and R. H. Holm, J. Am. Chem. Soc. 111, 1670 (1989).

18. J. Huang, S. Mukerjee, B. M. Segal, H. Akashi, J. Zhou, and R. H. Holm, J. Am. Chem. Soc. 119, in press (1997).

19. (a) L. Cai and R. H. Holm, J. Am. Chem. Soc. 116, 7177 (1994). (b) C. Zhou, L. Cai, and R. H. Holm, Inorg. Chem. 35, 2767 (1996).

20. J. Zhou, Z. Hu, E. Münck, and R. H. Holm, J. Am. Chem. Soc. 118, 1966 (1996).

21. J. Zhou, J. W. Raebiger, and C. A. Crawford, J. Am. Chem. Soc. 119, in press (1997).

22. L. M. Roberts and P. A. Lindahl, J. Am. Chem. Soc. 117, 2565 (1995).

23. J. W. Raebiger, C. A. Crawford, J. Zhou, and R. H. Holm, Inorg. Chem. 36, 994 (1997).

24. (a) J. N. Butt, F. A. Armstrong, J. Breton, S. J. George, A. J. Thomson, and E. C. Hatchikian, J. Am. Chem. Soc. 113, 6663 (1991). (b) M. G. Finnegan, R. C. Conover, J.-B. Park, Z. H. Zhou, M. W. W. Adams, and M. K. Johnson, Inorg. Chem. 34, 5358 (1995).

25. K. K. P. Srivastava, K. K. Surerus, R. C. Conover, M. K. Johnson, J.-B. Park, M. W. W. Adams, and E. Münck, Inorg. Chem. 32, 927 (1993).

26. J. Zhou, M. J. Scott, Z. Hu, G. Peng, E. Münck, and R. H. Holm, J. Am. Chem. Soc. 114, 10843 (1992).

27. J. B. Howard and D. C. Rees, Chem. Rev. 96, 2965 (1996).

28. (a) M. K. Chan, J. Kim, and D. C. Rees, Science 260, 792 (1993). (b) J. W. Peters, M. H. B. Stowell, S. M. Soltis, M. G. Finnegan, M. K. Johnson, and D. C. Rees, Biochemistry 36, 1181 (1997).

29. P. R. Challen, S.-M. Koo, W. R. Dunham, and D. Coucouvanis, J. Am. Chem. Soc. 112, 2455 (1990).

30. W. Cen, F. M. MacDonnell, M. J. Scott, and R. H. Holm, Inorg. Chem. 33, 5809 (1994).

31. R. E. Palermo, R. Singh, J. K. Bashkin, and R. H. Holm, J. Am. Chem. Soc. 106, 2600 (1984).

32. K. D. Demadis and D. Coucouvanis, Inorg. Chem. 34, 436 (1995)

33. S. W. Muchmore, R. F. Jack, and D. R. Dean. In Mechanisms of Metallocenter Assembly (R. P. Hausinger, G. L. Eichhorn, and L. G. Marzilli, eds.), chap. 6. VCH Publishers, Inc., New York (1996).

34. F. Osterloh, W. Saak, D. Hasse, and S. Pohl, J. Chem. Soc., Chem. Commun. 777 (1996).

35. (a) D. E. Robertson, R. S. Farid, C. C. Moser, J. L. Urbauer, S. E. Mulholland, R. Pidikiti, J. D. Lear, A. J. Wand, W. F. DeGrado, and P. L. Dutton, Nature 368, 425 (1994). (b) B. R. Gibney, S. E. Mulholland, F. Rabanal, and P. L. Dutton, Proc. Natl. Acad. Sci. USA 93, 15041 (1996). (c) B. R. Gibney, F. Rabanal, J. J. Skalicky, A. J. Wand, and P. L. Dutton, J. Am. Chem. Soc. 119, 2323 (1997). 